\title{
An Idol or an Ideal? A Case Study of Estonian E-Governance: Public Perceptions, Myths and Misbeliefs ${ }^{1}$
}

\author{
Tanel Kerikmäe \\ David Ramiro Troitiño \\ Olga Shumilo
}

\author{
Tallinn Law School, \\ Tallinn University of Technology \\ Akadeemia tee 3 , \\ Tallinn 12618, Estonia \\ E-mail: tanel.kerikmae@taltech.ee \\ E-mail: david.troitino@taltech.ee \\ E-mail: olshum@taltech.ee
}

\begin{abstract}
For over a decade, Estonia's fast track in implementing cuttingedge technologies remains in the focus of global public discourse, and has conquered young technocrats at home. With 'e-Estonia' being showcased as a national visit card, one of its intrinsic parts is e-governance-the framework of a seamless digital connection between the citizen and the state. Over the years of success, Estonian model has often been referred to as opposite, contrasting or different to the previous patterns of 'traditional public administration', and moreover-as a part of Estonian national idea and a value itself. The aim of this article is to analyse the place of the phenomenon of e-governance in Estonian cyberlibertarian discourse through the lens of the concepts of 'idol' and 'ideal public sphere' with subsequent connotations for local public policy.
\end{abstract}

Key words: case study, e-governance, Estonia, ICT tools, ideal, idolatry, philosophy, public sphere

This work was supported by the Estonian Research Council grant PUT 1628. 


\section{Introduction}

Since the early 2000s, Estonia has been building a digital society, which eventually gained global recognition (both in research and mass media) for eliminating bureaucracy and facilitating the interaction of the state and its citizens. The innovative national strategy is not only attracting start-up launchers and e-residents but also saves millions of euros for the state budget - for example, only introducing digital signatures is reportedly saving up to $2 \%$ of the annual GDP (IPI, 2016), and creates a strong, almost mythological, narrative of the "first" or "most wired" government in the world. For instance, in 2016, The Guardian published an article on Estonia as "the tiny European country that became a global leader in digital government", and The New Yorker followed the viral trend in a year with a reportage on a "digital republic" (Forbes, 2016) with a "virtual, borderless, blockchained and secure government" (Heller, 2017). Some other recent epithets worldwide include the labels of "the first digital nation", "the most digitally advanced society in the world", "a digital tiger", etc. Finally, Estonian government supports the new national brand and offers an open access toolkit for any e-Estonia spokesperson, featuring a motto "We Have Built a Digital Society-and So Can You".

On the one hand, the origin and motivation behind developing the abovementioned narrative is quite clear, as most nations in the world continuously look for a common idea to frame the society, justify a certain type of governance or simply to feel unique. Supranational communities and "immigrant" countries are no exclusion to the rule, as can be seen in the cases of the American "empire of liberty", or European "odyssey". On the other hand, the Estonian narrative of global digital leadership progress is different in many ways, as unlike others, it is based not on particular interpretations of history, monarchs or legends, but on the recent rapid rise of public administration in a small, resource-limited state, that took place in the span of less than 20 years.

The brand of Estonian e-government has attracted the attention of many political science scholars (see Björklund, 2016; Drechsler, 2018; Kimmo et al., 2018; Kitsing, 2018). The central points to argue are usually connected to the innovative nature of public governance and its benefits, or related to the struggles with e-participation, secure e-voting, and the contribution of the technologies to creating a welfare state. The controversy between the digital leadership known worldwide and the parallel shortcomings gives an incentive to examine how the Estonian e-governance adulation emerged into the national idea of "fully digital 
public administration", and could it make a positive contribution to or mislead the followers of the new era in public administration.

Hence, our article aims to address the public attitude towards the phenomenon of Estonian e-government, its "exclusivity" in the regional context, and address the possible misleading concepts. Despite covering some public policy, legal and policy matters, the main focus is on explaining the worship for technology in a complex societal setting, myths and speculations around its further potential. For this purpose, we have selected to apply the pattern of idolatry, as described by Goudzwaard (1984), and the multidisciplinary concept of ideal, to discover whether the discourse around Estonian e-governance is more inclined to see the latter as a value itself or a perfect model yet to achieve. Goudzwaard's understanding of idolatry has been previously applied by Krishnan-Harihara and Basden (2010) to the e-government concept as a whole, thus the case study will closely examine the specific country context and outcomes. The political ideal theory, based on the findings of Max Weber, is currently set in dichotomy with the non-ideal theory, which suggests two different approaches to perceiving absolute public policy goals like justice, equality, etc.

\section{Estonia's idol: how did two simple solutions capture everyone's mind?}

Will technologies eventually save humanity or approach the apocalypse? Nobody knows. But so far, our civilization undoubtedly owes too much to the discoveries that eradicate our mundane routine, cure the incurable diseases, and expand the horizons. Since the legend of Prometheus, technology in its broadest context has been involved not only in economic, but political and societal transformations as well. The potential of technologies to make a considerable impact on health, knowledge, freedom, independence, and security were tempting to some degree of worship from the beginning but entered into full force only in the Enlightenment époque. Some of the noteworthy mentions are the romantic "railway philosophy" ideas in the setting of nineteenth-century Canada building the transcontinental transport channel (Den Otter, 1997, p. 205), or the intense "electrification" ideology (as opposed to the superstitious and parochial "dark tsarist times") in the early years of Soviet Russia (Chadaga, 2007). 
Bearing this in mind, one must admit that the framework of e-governance was more than just another invention reducing the burden of human labor and intensifying productivity. Bringing the communication of the government and its citizens online has made a tremendous change in the public mindset. Moreover, the contrast between a formalized bureaucratic interaction in the past, on the one hand, and the seamless "customer-provider" approach on the other hand was colossal in a post-Soviet country, with a couple of generations still remembering the hierarchy and barriers of the communist government red tape. Thus, when the ID card and X-Road core duo was presented and supported by Estonian and foreign public, not only the fast track of constructing digital governance system, but also the post-totalitarian foundation and the scarcity of resources were taken into account. Relevant criticisms were expressed as well; anyhow, for the purpose of the article we only considered recent publications dealing with partial or total support for Estonian model of e-governance. Below we allocate the key features of idolatry (according to Goutzwaard) with the respective theses, opinions, and ideas expressed by Estonian and international officials, academia, political observers and experts.

\section{Different from its immediate environment}

Although every state adopting digital governance is somewhat inclined to present a completely different system of government-citizen connection, in Estonia this difference has been specifically outlined for the rapid progress from a "disconnected" post-socialist state in 2000 (Vassil, 2015) to "the most advanced digital society" in 2017 (Hammersley, 2017). The transformation process has smoothly separated the on-line and off-line universes of many public administration domains, such as (1) democracy and legitimacy of institutions; (2) provision of services; (3) justice and regulatory framework; (4) international relations; etc.

\section{Refashioned}

Moreover, some argue that the whole understanding of traditional public institutes has changed. According to Andres Kütt, who represents the Estonian Information System Authority, the online ID system is an attempt to redefine "the nature of the country" and "reinventing government" (Keen, 2017).

\section{Erect in a special place}

As usually displayed, the core of e-governance is the mandatory physical ID card, and the "busiest road of Estonia" - the X-Road, which represents the 
interconnectivity between all the offices and ministries. The two elements meet on the government information portal, eesti.ee, where one can request services and access personal data collected by the government. The ID card and Smart-ID login technologies are often referred to as the most secure and efficient means of personal identification. For example, the latest version of the card includes a contactless interface, "also utilizes Estonia's own font and elements of its brand" (Invest in Estonia, 2018).

\section{Ritual consecration}

Voting has often been referred to as a ritual of public administration due to its many symbols, slightly reminding spiritual ones—cycles of power change, secrecy of casting the ballot, making the inner choice audible, etc. In Estonia, e-voting has been given special attention, as in 2005 and 2007 the option to vote online was a global breakthrough. Highlighting the participatory element by changing the usual mechanism and external environment of voting, driven by convenience, gained trust among Estonians and in ten years over 30\% of votes are collected online (Invest in Estonia, 2018).

\section{5. "Life" of its own}

In a religious pattern, any idol is believed to have a "life" of its own. Administrationwise, the system of digital connections is dependent on multiple actors, but is it also capable of influencing the off-line environment? In Estonia, e-governance is a constantly updated and enlarged system, which provides grounds for new ambitious incentives, for example e-residency, which was launched ten years after the digital challenge started-in 2014.

\section{Given "sacrifices"}

The most often debated topic for the opponents of e-governance is the risk of personal data leaks. Anyhow, Estonian officials present e-governance as a fair deal, where a citizen exchanges personal data for convenience and velocity in resolving bureaucracy issues. Considering the recent erosion of trust in government global wave, it would be unsurprising to notice any calls for a reverse movement in Estonia as well, but the country's level of trust remains higher than the EU average, hitting $44 \%$ of satisfied citizens (Jackson, 2018). 


\section{Expected repayment}

One of the key features of Estonian e-governance is the positive pay-offs. The innovative solutions are praised by the advocates for increased convenience, which is reflected in the calculations of the saved GDP per annum. In one of the largest research made on the issue, it has been stated that every request saves around 15 minutes of citizen's time (Vassil, 2015).

\section{Harmful}

Any modern idol brings harm to its worshippers, according to Goutzwaard, but is e-governance the case? The critics of Estonian e-governance refer to the concept as "e-Narnia" (Vaarik, 2015), a mythical non-existing creature of technopopulists' fantasy, or as a major threat to national cyber-security. These fears are based on a traumatic experience-in 2007, the country's main digital systems were under cyber-attacks of allegedly Russian origin, that have inspired complete redesign of not only national but international military doctrine as well (Herzog, 2011). Other potential risks reported so far are limited to putting the digital services ahead of other priorities (e.g., instead of increasing the welfare of the underprivileged), not considering the existing digital divide between the generation, or as a threat to privacy, etc. Brief statistical research shows that the mentioned threats are present, but since 2007 keep being successfully neutralized by the government's efforts. For example, when in 2017 the Czech scientists identified a threat in the digital ID cards, the whole system was suspended for a short time until recovery (e-Estonia, 2018).

\section{If not an idol, perhaps an ideal?}

As stated in the initial part, another point of view for explaining the public "hype" over Estonian e-governance could be an "ideal" model of public service's ultimate goal for state-citizen interaction, with minor abstractions and perfection. The concept of ideal has emerged from Latin idealis, or "existing in idea" (Thesaurus, n.d.), and now has a wide spectrum of interpretations in modern philosophy and political science. Moral ideals were core to Kantian ethics, Max Weber came up with the ideal type as a "pure model" of typologies for social sciences, and in the second half of the 20th century John Rawles split philosophers into supporters and opponents to his ideal theory of social justice. Ideals as "perfect 
landmarks" are also sometimes examined within the crux of political science and multi-disciplinary humanities, for example, the ideals of freedom (Wall, 2003), civil society (Seligman, 2002), religious autonomy (Wenger, 2017), or a hypothetically created ideal digital judge (Kerikmäe \& Särav, 2017, pp. 205, 222) of the future. The concept of an ideal public service in the US has been meticulously examined by Ann Simeone (2004), with a particular focus on how the modern paradigm of cost-efficient public management challenges the classical perception of 'ideal' governance in the country, based on the analysis of American presidents' inaugural addresses.

The criteria for each of these ideals (both universal and country-specific) are defined with relevance to specific domain, but the common feature for all is being a polar star to the wide public, researchers and policy-makers, and helping to share the vision and strategy of further transformations with developing countries. As noted by Kerikmäe (2015), rule of law can only be observed in a perfect (thus non-existent) state, which however does not diminish the significance of exploring the domain in all dimensions. Thus, we posit the discourse around Estonian e-governance leadership to align with an 'ideal' concept, which offers a tentative model of a remarkably successful digital government that has been created with much effort and trust from Estonian citizens under far from perfect economic conditions, and helps to share worldwide the benefits of digital governance, as well as cope with new challenges.

\section{Conclusions}

The constant search for new discoveries is bringing human civilization to the age of breath-taking solutions and the world as close to each other as never before. The example of Estonia and its innovative e-governance branding in this regard can be either simplified to an "e-Narnia" or seen as one of the pioneering cases in transforming the traditional hierarchal and exclusive public administration structure into a network of common benefit. There are certain tracks of hyperbolized positive feedback to the existing privileges of living in the "digital society", which, however, do not stop the architects of e-governance from further diffusion both inside and outside the country. The philosophical concept of ideal public sphere reflects most of the current Baltic republic's agenda. The local and international perceptions of Estonian e-governance mostly reflect an "ideal" mindset, with displaying the existing model as a possible cure to other countries' 
Tanel Kerikmäe

David Ramiro Troitiño

Olga Shumilo

inner public administration problems and abstracting from other success stories in the region, but mostly looking at Estonia as a pathfinder to learn from.

\section{References}

Björklund, F. (2016), 'E-government and moral citizenship: the case of Estonia,' Citizenship Studies, vol. 20, nos. 6-7, pp. 914-931. https://doi.org/10.1080/13621025.2016.1213222

Chadaga, J. B. (2007), 'Light in captivity: spectacular glass and Soviet power in the 1920s and 1930s,' Slavic Review, vol. 66, no. 1, pp. 82-105. https://doi.org/10.2307/20060148

Den Otter, A. A. (1997), The Philosophy of Railways: The Transcontinental Railway Idea in British North America, Toronto: University of Toronto Press. https://doi.org/10.3138/9781442678460

Drechsler, W. (2018), 'Pathfinder: e-Estonia as the $\beta$-version,' JeDEM: eJournal of eDemocracy and Open Government, vol. 10, no. 2, pp. 1-22. https://doi.org/10.29379/jedem.v10i2.513

e-Estonia (2018), 'What we learned from the eID card security risk?' 28 June. Retrieved from https://e-estonia.com/card-security-risk/ [accessed 18 Mar 2019]

Forbes (2016), 'The tiny European country that became a global leader in digital government,' 14 June. Retrieved from https:/www.forbes.com/sites/ delltechnologies/2016/06/14/the-tiny-european-country-that-became-a-globalleader-in-digital-government/\#65ba6894e13a [accessed 1 Feb 2019]

Goudzwaard, B. (1984), Idols of Our Time, Downers Grove: Inter-Varsity Press.

Hammersley, B. (2017), 'Concerned about Brexit? Why not become an e-resident of Estonia?’ Wired, 27 March. Retrieved from https://www.wired.co.uk/article/estoniae-resident [accessed 18 Mar 2019]

Heller, N. (2017), 'Estonia, the digital republic,' The New Yorker, 25 December. Retrieved from https://www.newyorker.com/magazine/2017/12/18/estonia-thedigital-republic [accessed 15 Mar 2019]

Herzog, S. (2011), 'Revisiting the Estonian cyberattacks: digital threats and multinational responses,' Journal of Strategic Security, vol. 4, no. 2, pp. 49-60.

https://doi.org/10.5038/1944-0472.4.2.3

Invest in Estonia (2018), 'Estonia's new ID card introduced - a contactless card of the 21 st century.' Retrieved from https://investinestonia.com/estonias-new-id-cardintroduced-a-contactless-card-of-the-21st-century/ [accessed 18 Mar 2019]

IPI (2016), 'Estonia PM: Country saves 2\% GDP by going digital, International Peace Institute, 3 May. Retrieved from https:/www.ipinst.org/2016/05/informationtechnology-and-governance-estonia\#1 [accessed 1 Feb 2019] 
Jackson, E. (2018), 'The right mix: how Estonia ensures privacy and access to e-services in the digital age,' $e G A$. Retrieved from https://ega.ee/news/the-right-mix-howestonia-ensures-privacy-and-access-to-e-services-in-the-digital-age/ [accessed 18 Mar 2019]

Keen, A. (2018), 'Where in the world will you find the most advanced e-government? Estonia,' TED, 15 March. Retrieved from https://ideas.ted.com/where-in-theworld-will-you-find-the-most-advanced-e-government-estonia/ [accessed $18 \mathrm{Mar}$ 2019]

Kerikmäe, T. (2015), 'European history and the future of legal freedoms,' Baltic Journal of European Studies, vol. 5, no. 2, pp. 3-4. https://doi.org/10.1515/bjes-2015-0010

Kerikmäe, T. \& Särav, S. (2017), 'Paradigms for automatization of logic and legal reasoning,' in D. Krimphove \& G. M. Lentner (eds.) Law and Logic: Contemporary Issues, Berlin: Duncker \& Humblot, pp. 206-223.

Kimmo, M.; Pappel, I. \& Draheim, D. (2018), 'E-residency as a nation branding case,' in Proceedings of the 11th International Conference on Theory and Practice of Electronic Governance, New York: ACM, pp. 419-428. https://doi.org/10.1145/3209415.3209447

Kitsing, M. (2018), 'The Janus-faced approach to governance: a mismatch between public sector reforms and digital government in Estonia,' in Proceedings of the 11th International Conference on Theory and Practice of Electronic Governance, New York: ACM, pp. 59-68. https://doi.org/10.1145/3209415.3209453

Krishnan-Harihara, S. \& Basden, A. (2010), 'Is idolatry a suitable tool to test e-government?’ in R. Goede, L. Grobler \& D. E. Haftor (eds.) Interdisciplinary Research for Practices of Social Change. Proc. 16th Annual Working Conference of the Centre for Philosophy, Technology and Social Systems (CPTS), Maarssen; BZ Repro, pp. 107-125.

Seligman, A. B. (2002), 'Civil society as idea and ideal,' in S. Chambers \& W. Kymlicka (eds.) Alternative Conceptions of Civil Society, Princeton \& Oxford: Princeton University Press, pp. 13-33.

Simeone, A. E. (2004), The Ideal of Public Service: The Reality of the Rhetoric, Doctoral dissertation, Virginia Tech.

Thesaurus (n.d.), 'Ideal.' Retrieved from https://www.thesaurus.com/browse/ideal [accessed 18 Mar 2019]

Vaarik, D. (2015), Where Stuff Happens First: White Paper on Estonia's Digital Ideology. Retrieved from https://www.mkm.ee/sites/default/files/digitalideology_final.pdf [accessed 18 Mar 2019]

Vassil, K. (2015), Estonian e-Government Ecosystem. Foundation, Applications, Outcomes, World Bank. Retrieved from http://pubdocs.worldbank.org/ en/165711456838073531/WDR16-BP-Estonian-eGov-ecosystem-Vassil.pdf [accessed 18 Mar 2019] https://doi.org/10.1017/S0265052503202132 
Wall, S. (2003), 'Freedom as a political ideal,' Social Philosophy and Policy, vol. 20, no. 2, pp. 307-334.

Wenger, T. (2017), Religious Freedom: The Contested History of an American Ideal, Chapel Hill: UNC Press. https://doi.org/10.5149/northcarolina/9781469634623.001.0001

Tanel Kerikmäe is a full professor of law, contributing in the field of European law and policies. His research group of law \& tech has received significant funding from EU Commission, NATO, Folke Bernadotte Academy, USAID, etc. and is focused on developing legal digital skills. Kerikmäe has been contributing to Springer, Ashgate, Kluwer, Oxford and Cambridge publishers and is a foreign member of the National Academy of Legal Sciences of Ukraine and a visiting professor of HCMC Law University. His articles include topics on EU legal policies, constitutional law, digital single market, automatization, legal impediments to new technologies, augmented and artificial intelligence in legal practice. He is supervising doctoral students in Helsinki, Lausanne, Tallinn, Medellin, and Kaunas. https://www.etis.ee/CV/Tanel_Kerikmäe/ est?lang=ENG

David Ramiro Troitiño is currently an associate professor at the University of Technology of Tallinn, Estonia. He studied at the University of Salamanca, where he finished his PhD studies in the European Union with highest honors. His first book European Integration: Building Europe is a result of many years of teaching in different universities of Europe. He is also the author of several international articles and has been speaker at different international conferences, all related to the European Union. His main interest is the development of the European Union and the future scenarios.

Olga Shumilo is a PhD student, writing her thesis on issues of legal framework for smart cities. At TalTech, she is teaching courses on penal and administrative law, and has contributed to several publications in the scope of EU law and e-governance. Olga has obtained her master's degree (cum laude) and first doctoral degree at the Yaroslav Mudryi National Law University (Kharkiv, Ukraine) in criminal law and criminology. In Ukraine, Olga has also been actively advocating for animal welfare and human rights. 